\title{
THE USE OF NONINVASIVE BRAIN STIMULATION TECHNIQUES TO MODULATE IMPULSIVITY
}

\author{
Laura Mauer ${ }^{1}$, Cheng-Chang Yang ${ }^{2}$, Najat Khalifa ${ }^{3,4}$ \\ ${ }^{I}$ Institute of Clinical Psychology and Psychotherapy, Technical University of Dresden, Germany, \\ ${ }^{2}$ Division of Psychiatry and Applied Psychology, School of Medicine, University of Nottingham, UK, \\ ${ }^{3}$ Department of Psychiatry, Queen's University, Ontario, Canada, \\ ${ }^{4}$ Wells Road Centre, Nottinghamshire Healthcare NHS Foundation Trust, Nottingham, UK
}

Key words: impulsivity, TMS, tDCS, noninvasive brain stimulation, response inhibition, delay discounting.

\begin{abstract}
Summary
Several of the disorders categorised in the Diagnostic and Statistical Manual of Mental Disorders (DSM-5) are marked by impulsivity, including borderline and antisocial personality disorders, attention deficit hyperactivity disorder, conduct disorder and substance use disorders, just to name a few. The behavioural manifestations of impulsivity are numerous (e.g., suicidality, reckless spending, criminality, acting out on positive or negative emotions), often with undesirable consequences for the individuals involved and others. The knowledge base in respect of the neurobiological underpinnings of impulsivity has expanded significantly over the past few decades, providing the impetus to develop specific interventions to target impulsivity. Noninvasive brain stimulation techniques, such as Transcranial Magnetic Stimulation (TMS) and Transcranial Direct Current Stimulation (tDCS), have been used to modulate impulsivity with promising results. This article aims to provide a brief overview of the literature in the field before addressing the implications for future research and clinical practice.
\end{abstract}

\section{Introduction}

Impulsivity is a key attribute of several psychiatric disorders, and the behavioural manifestations of impulsivity are numerous (e.g. self-harm, violence and aggression, criminality, reckless spending), often with undesirable consequences for the individuals concerned and the wider society. The knowledge base in respect of the conceptualisation and neurobiological underpinnings of impulsivity has grown steadily over the past few decades, and this in conjunction with the societal burden of the disorders that are marked by impulsivity, provides the impetus to develop specific interventions to reduce impulsivity.

Indication. This article aims to provide a brief overview of the literature on impulsivity, in terms of conceptualisation and measurement, and the use of noninvasive brain stimulation techniques to modulate impulsivity.

Impulsivity. A tendency to act without thinking through the consequences of one's actions is a core attribute of impulsivity. Impulse control is a multi-dimensional construct that incorporates cognitive, motor and temporal procosses [1, 2]. These processes overlap significantly with each other and with decision making. Attention and short-term memory also play a role in impulse control and decision making. Deficits in these processes are manifested as cognitive, temporal or motor impulsivity. A tendency to make risky or disadvantageous decisions without utilising enough information can be construed as cognitive impulsivity, whereas failure to inhibit a prepotent behavioural response is regarded as a form of motor impulsivity. In contrast, temporal impulsivity is thought to be underpinned by failure to delay gratification $[2,3]$.

Impulsivity and mental disorder. Current psychiatric classification systems, such as the International Classification of Diseases, Tenth Edition (ICD-10) [4], and the Diagnostic and Statistical Manual of Mental Disorders, Fifth Edition (DSM-5) [5], include impulsivity in the diagnostic criteria of several disorders. These include attention deficit hyperactivity disorder (ADHD), conduct disorder, antisocial (or dissocial) personality disorder, borderline (emotionally unstable) personality disorders, impulse-control disorders and substance use disorders (SUD). Additionally, impulsivity is regarded as an important consideration in the field of risk assessment and management [6] owing to its association with suicidality [7], poor concordance with treatment [8] and criminality [9]. 
Measures of impulsivity. Current measures of impulsivity fall into two main categories; self-report and behavioural. Existing evidence suggests that behavioural and self-report measures of impulsivity have distinct neurobiological underpinnings, and as such they do not significantly correlate with each other [10].

Commonly used self-report (also known as trait) measures of impulsivity include the Barrett Impulsiveness Scale (BIS-11) [11] and the UPPS-P Impulsive Behavior Scale [12]. The BIS-11 is comprised of 30 items that merge to form 3 subscales: attentional, motor and non-planning impulsiveness. Each item is measured on a scale of 1-4 (1=rarely/ never, $2=$ occasionally, $3=$ often, $4=$ almost always/always), giving a total score out of 120 . UPPS-P is a 59 item selfreport measure of impulsivity with five subscales; Negative Urgency, (lack of) Premeditation, (lack of) Perseverance, Sensation seeking and Positive Urgency. Each item is rated on a scale of $1-4(1=$ totally disagree, $4=$ totally agree $)$ giving a total UPPS-P score out of 236. Higher scores on both BIS11 and UPPS-P denote greater impulsivity.

Behavioural measures of impulsivity utilise laboratory paradigms (or computerised tasks) to assess impulsivity based on task performance. Motor impulsivity, for instance, is assessed using the Go-No-Go (GNG) task [13], the Stroop Color and Word Test (SWCT) [14], the Stop-Signal-Task (SST) [15] and the Continuous Performance Task (CPT) [16]. Temporal impulsivity is assessed using tasks designed to measure delayed discounting. Tasks such as the Iowa Gambling Task (IGT) [17], the Information Sampling (IST) Task [18] and the Balloon Analogue Risk Task (BART) [19], are used to index cognitive impulsivity. Describing each task is beyond the scope of this article. For illustration purposes, a brief description of the SST is provided. A computerised version of the SST can be administered as part of the Cambridge Computerised Neuropsychological Battery (CANTAB) [20]. The task entails presenting a circle on the computer screen with an arrow inside pointing either to the right or left of the screen (the go signal). The participant is instructed use a pad to register their responses by pressing the left hand button on the pad for arrows pointing to the left or the right hand button for arrows pointing to the right. The participant is instructed to withhold response upon hearing a beeping sound (the auditory stop signal) which is randomly generated shortly after the presentation of the arrows in $25 \%$ of the trials. The task consists of five blocks with 64 trials in each block. It takes 15 minutes to complete the SST.

Neurobiology of impulsivity. Evidence from the neurobiological literature suggests that impulsivity is influenced by the activation of several neuronal circuits in the brain [21], and hypoactivity of various regions of the prefrontal cor- tex (PFC) has been linked to increased cognitive, temporal and motor impulsivity [22]. A fronto-subcortical network including the right inferior frontal gyrus (rIFG), the presupplementary motor area, the anterior cingulated cortex (ACC) and the basal ganglia has been implicated in motor impulsivity $[23 ; 23 ; 25]$. A fronto-limbic network comprising of the ventral medial prefrontal cortex (vmPFC), ACC, and nucleus ventral striatum [21] plays a prominent role in temporal impulsivity. The activation of the vmPFC has been implicated in cognitive impulsivity [26].

Interventions to target impulsivity. Impulsivity is a prominent feature of several mental disorders and can have undesirable consequences for the individuals and a considerable societal burden. Both pharmacological and psychological [28] interventions have been used to reduce impulsivity, albeit only in the context of a wider behavioural disturbance rather than in isolation. The knowledge base around impulsivity has grown steadily in the past few decades, and this can inform the development of specific interventions to target impulsive behaviour. Existing evidence suggests that noninvasive brain stimulation techniques can potentially be used to modulate impulsive behaviour.

Noninvasive brain stimulation techniques. The past two decades have witnessed a significant expansion in the use of noninvasive brain stimulation (NIBS) techniques, like repetitive transcranial magnetic stimulation (rTMS) and transcranial direct current stimulation (tDCS), in clinical practice [29].

TMS is a neuromodulation technique used to modulate the excitability of neurons through the administration of a single pulse (spTMS) or repetitive (rTMS) high-intensity magnetic pulses through an electromagnetic coil placed over the scalp [30]. Magnetic pulses are generated by passing electric currents through the coil, producing a focal magnetic field which induces localised neuronal depolarization in the brain areas underneath the stimulation site [31]. Low frequency rTMS (1 Hz or less) reduces cortical excitability, whereas high frequency rTMS (about $5 \mathrm{~Hz}$ or more) increases cortical excitability [32]. Theta burst stimulation (TBS), a form of high-frequency rTMS, entails delivering pulses in bursts of three stimuli with an inter-burst interval of 200 $\mathrm{ms}$ at $50 \mathrm{~Hz}$ but with reduced magnetic intensity [33; 34]. While continuous TBS (cTBS) decreases cortical excitability, intermittent TBS (iTBS) has the opposite effect [35].

tDCS is a technique used to deliver a weak direct current (up to $2 \mathrm{~mA}$ ) to the brain through scalp electrodes to induce a polarization of the neuronal membrane [29]. Anodal tDCS enhances cortical excitability, while cathodal tDCS exerts 
an inhibitory effect [36]. The strength and duration of tDCS after-effects are determined by the intensity of the current and duration of stimulation [37].

Both rTMS and tDCS are well tolerated, although they may cause adverse effects. Headache, transient hearing change due to the noise and neck pain are among the most commonly reported side effects of TMS, experienced by $20-40 \%$ of subjects undergoing TMS [30; 38]. TMS also carries a very small risk of inducing epileptic seizures [39]. Syncope during TMS administration has also been reported [30]. The adverse effects of tDCS also include headache and neck pain, as well as tingling and burning sensation at the site of stimulation, trouble concentrating and acute mood changes [40].

Efficacy of TMS in reducing impulsivity. TMS has been used to treat a range of neuropsychiatric disorders such as Parkinson's disease [41], obsessive-compulsive disorder [42], schizophrenia [43]; post traumatic stress disorder [44], and major depression [45]. In addition, findings from two major systematic reviews in the field demonstrated its efficacy in reducing impulsivity $[2 ; 46]$.

The review by Brevet-Aeby and colleagues [44] highlighted several findings that are worthy of note here. First, both low frequency rTMS and cTBS applied individually to the right IFG during a Stop-Signal-Task increased inhibitory control, whereas low frequency rTMS applied to the left IFG or the right dorso-lateral prefrontal cortex (DLPFC) had no significant effects on impulsivity. Second, high-frequency rTMS applied to the left DLPFC led to an improvement in inhibitory control, while low-frequency rTMS targeting the left DLPFC had no significant effects. Third, low frequency rTMS over the right DLPFC reduced risk taking behaviour, but no significant changes were evident for stimulation over the left DLPFC. Fourth, cTBS over the right DLPFC lowered immediate reward choices, whereas low frequency rTMS over the left DLPFC had the opposite effect. Finally, high frequency bilateral rTMS applied to the DLPFC decreased impulsivity. In short, the review by Brevet-Aeby and colleagues [46] provides evidence that both excitatory (high frequency) rTMS applied to the left DLPFC and inhibitory (low frequency or cTBS) rTMS applied to the right DLPFC or IFG can reduce impulsivity. The review also provides evidence that excitatory rTMS is more effective than inhibitory rTMS in reducing impulsivity.

The systematic review and meta-analysis by Yang and colleagues [2] provides further evidence that rTMS can reduce both temporal and motor impulsivity in non-clinical samples. The review demonstrates that rTMS has a small effect on modulating motor impulsivity and a moderate effect on temporal impulsivity but no significant effects on cognitive impulsivity. The review also identified some of the key parameters required to enhance the effects of rTMS on impulsivity. A major advantage this review had over previous reviews is that it entailed conducting a metaanalysis to quantify the effects of rTMS on impulsivity and its subdomains. The evidence reviewed was judged to be of moderate quality. However, the review identified several weaknesses in the studies included in the review such as selection bias, small sample sizes, heterogeneity of designs and outcome measures used, and lack of information on the adverse effects of rTMS.

Efficacy of tDCS in reducing impulsivity. tDCS has shown a promising potential in the treatment of a range of mental disorders including substance use disorders, schizophrenia and depression [47].

The review by Brevet-Aeby and colleagues [46] presented a range of findings in regards to the use of tDCS for impulsivity. Studies included in the review provided evidence that unilateral anodal tDCS of the IFG enhanced inhibitory control, whereas cathodal tDCS did not have a significant effect. Without hemispheric distinction, bilateral anodal and cathodal tDCS of the IFG during an SST task enhanced inhibitory control, while bilateral tDCS of the IFG during a GNG task did not have a significant effect. In contrast to this, the review revealed that right anodal and left cathodal tDCS of the IFG in the GNG task decreased impulsivity. Anodal tDCS stimulation over the right DLPFC seemed to have had no substantial impact on inhibitory control in several studies. However, cathodal tDCS of the same region resulted in reduced inhibitory control. In the Stroop task, bilateral left anodal/right cathodal tDCS enhanced inhibitory control as well. Other studies reported decreased risk taking especially after bilateral tDCS of the DLPFC. Risk taking was significantly reduced if the stimulation was right-anodal/ left-cathodal. However, during a delay discounting task, left anodal and right cathodal tDCS of the DLPFC increased impulsivity. Overall, the results of the review [46] highlighted that right anodal/left cathodal tDCS over the DLPFC is more effective than left anodal/right cathodal tDCS.

\section{Directions for future research}

Future investigations on the therapeutic effects of noninvasive brain stimulation techniques on impulsivity should consider clinical populations. The authors are in the process of conducting a systematic review and meta-analysis of the literature on the effects of TMS and tDCS on impulsivity in people with mental disorders. This area appears to have attracted little attention in the recent literature, an important 
gap that future studies can fill. Robust data on the efficacy of brain stimulation techniques to modulate impulsivity in disorders that are marked by impulsivity is lacking, and this makes it difficult to identify the conditions that benefit most from the use of such techniques.

\section{Conclusions}

The use of noninvasive brain stimulation techniques to modulate brain activity is an emerging field both in research and clinical practice, with promising results. There is empirical evidence in support of the use of both TMS and tDCS to modulate impulsivity, particularly in respect of the use of excitatory rTMS to modulate temporal and motor impulsivity and right anodal-left cathodal tDCS to enhance inhibitory control. However, the current evidence should be interpreted with caution owing to the methodological limitations of the studies conducted to date. Although the evidence base for the use of brain stimulation is growing rapidly, more research is required to identify the parameters needed to maximise effects, for instance, in terms of stimulation sites, impulsivity tasks and stimulation parameters for brain stimulation [2; 47]. Additionally, more research involving a concurrent use of TMS or tDCS and neuroimaging techniques is required to assess the mechanism of action of both TMS and tDCS in the neuromodulation of impulsivity. Furthermore, the role of connectivity guided brain stimulation should be explored further since impulsivity is regulated by brain networks rather than a single brain region.

\section{References}

1. Caswell AJ, Celio MA, Morgan MJ, Duka T. Impulsivity as a multifaceted construct related to excessive drinking among UK students. Alcohol Alcohol 2016; 51(1): 77-83.

https://doi.org/10.1093/alcalc/agv070

2. Yang CC, Völlm B, Khalifa N. The effects of rTMS on impulsivity in normal adults: a systematic review and meta-analysis. Neuropsychol Rev 2018; 1-16.

https://doi.org/10.1007/s11065-018-9376-6

3. Verdejo-Garcia A, Lawrence AJ, Clark L. Impulsivity as a vulnerability marker for substance-use disorders: review of findings from high-risk research, problem gamblers and genetic association studies. Neurosci Biobehav Rev 2008; 32(4): 777-810. https://doi.org/10.1016/j.neubiorev.2007.11.003

4. World Health Organisation (1992). Tenth Revision of the International Classification of Diseases (ICD-10), 1992; Geneva: WHO.

5. American Psychiatric Association. Diagnostic and Statistical Manual of Mental Disorders (DSM-5), 2013; Washington: American Psychiatric Publishing.

6. McGuire J. "Assessing Risk of Violence in Offenders with Mental
Disorders", in: Assessments in Forensic Practice. (eds.) KD Browne, AR Beech, LA Craig \& S Chou. 2017; 139.

7. Richard-Devantoy S, Gorwood P, Annweiler C, Olié JP, Le Gall $\mathrm{D}$, Beauchet O. Suicidal behaviours in affective disorders: a deficit of cognitive inhibition? Can J Psychiatry 2012; 57 (4): 254-262.

https://doi.org/10.1177/070674371205700409

8. Cancel A, Naudet F, Rousseau PF, Millet B, Drapier D. Impulsivity: what are the consequences on compliance to rehabilitation? Encephale, 2016; 42: 314-319.

https://doi.org/10.1016/j.encep.2015.12.009

9. Bjørkly S. A systematic review of the relationship between impulsivity and violence in persons with psychosis: evidence or spin cycle? Aggr Violent Behav 2013; 18: 753-760.

https://doi.org/10.1016/j.avb.2013.08.001

10. Caswell AJ, Bond R, Duka T, Morgan MJ. Further evidence of the heterogeneous nature of impulsivity. Pers Individ Dif 2015; 76: 68-74.

https://doi.org/10.1016/j.paid.2014.11.059

11. Barratt ES. Factor analysis of some psychometric measures of impulsiveness and anxiety. Psychological reports 1965; 16(2): 547-554.

https://doi.org/10.2466/pr0.1965.16.2.547

12. Cyders MA, Smith GT, Spillane NS, Fischer S, Annus AM, Peterson C. Integration of impulsivity and positive mood to predict risky behavior: development and validation of a measure of positive urgency. Psychol assess 2007; 19(1): 107.

https://doi.org/10.1037/1040-3590.19.1.107

13. Gomez P, Ratcliff R, Perea, M. A model of the go/no-go task. J Exp Psychol 2007; 136(3): 389.

https://doi.org/10.1037/0096-3445.136.3.389

14. Stroop JR. Studies of interference in serial verbal reactions. J Exp Psychol 1935; 18: 643-662.

https://doi.org/10.1037/h0054651

15. Logan GD. "On the ability to inhibit thought and action. A users' guide to the stop signal paradigm," in Inhibitory processes in attention, memory and language, eds. D Dagenbach, TH Carr. (San Diego (CA): Academic Press) 1994; 189-236.

16. Conners CK, Epstein JN, Angold A, Klaric J. Continuous performance test performance in a normative epidemiological sample. J Abnorm Child Psychol 2003; 31: 555-562.

https://doi.org/10.1023/A:1025457300409

17. Bechara A, Damasio AR, Damasio H, Anderson SW. Insensitivity to future consequences following damage to human prefrontal cortex. Cognition 1994; 50: 7-15.

https://doi.org/10.1016/0010-0277(94)90018-3

18. Clark L, Robbins TW, Ersche KD, Sahakian BJ. Reflection impulsivity in current and former substance users. Biol Psychiatry 2006; 60: 515-522.

https://doi.org/10.1016/j.biopsych.2005.11.007

19. Lejuez CW, Read JP, Kahler CW, Richards JB, Ramsey SE, 
Stuart GL, Brown RA. Evaluation of a behavioral measure of risk taking: the Balloon Analogue Risk Task (BART). J Exp Psychol Appl 2002; 8: 75-84.

https://doi.org/10.1037/1076-898X.8.2.75

20. Cambridge Cognition. 2016; CANTAB ${ }^{\circledR}$ [Cognitive assessment software]: CANTAB Technology.

21. Grant JE, Kim SW. Brain circuitry of compulsivity and impulsivity. CNS Spectrums 2014; 19: 21-27.

https://doi.org/10.1017/S109285291300028X

22. Dalley JW, Everitt BJ, Robbins TW. Impulsivity, compulsivity, and top-down cognitive control. Neuron 2011; 69(4): 680-694. https://doi.org/10.1016/j.neuron.2011.01.020

23. Aron AR, Fletcher PC, Bullmore ET, Sahakian BJ, Robbins TW. Stop-signal inhibition disrupted by damage to right inferior frontal gyrus in humans. Nat Neurosci 2003; 6: 115-116. https://doi.org/10.1038/nn1003

24. Chambers CD, Garavan H, Bellgrove MA. Insights into the neural basis of response inhibition from cognitive and clinical neuroscience. Neurosci Biobehav Rev 2009; 33: 631-646. https://doi.org/10.1016/j.neubiorev.2008.08.016

25. Wilbertz T, Deserno L, Horstmann A, Neumann J, Villringer A, Heinze HJ, ..., Schlagenhauf F. Response inhibition and its relation to multidimensional impulsivity. NeuroImage 2014; 103: 241-248.

https://doi.org/10.1016/j.neuroimage.2014.09.021

26. Bechara A. The role of emotion in decision-making: evidence from neurological patients with orbitofrontal damage. Brain Cogn 2004; 55: 30-40.

https://doi.org/10.1016/j.bandc.2003.04.001

28. Gooding P, Tarrier N. A systematic review and meta-analysis of cognitive-behavioural interventions to reduce problematic gambling: hedging our bets? Behav Res Ther 2009; 47: 592-607. https://doi.org/10.1016/j.brat.2009.04.002

29. Brunoni AR, Nitsche MA, Bolognini N, Bikson M, Wagner T, Merabet L, ..., Fregni F. Clinical Research with Transcranial Direct Current Stimulation (tDCS): challenges and future directions. Brain Stimul 2012; 5: 175-195.

https://doi.org/10.1016/j.brs.2011.03.002

30. Rossi S, Hallett M, Rossini PM, Pascual-Leone A, The Safety of TMS Consensus Group. Safety, ethical considerations, and application guidelines for the use of transcranial magnetic stimulation in clinical practice and research. Clin Neurophysiol 2009; 120: 2008-2039.

https://doi.org/10.1016/j.clinph.2009.08.016

31. Wagner T, Valero-Cabre A, Pascual-Leone A. Noninvasive human brain stimulation. Annu Rev Biomed Eng 2007; 9: $527-565$.

https://doi.org/10.1146/annurev.bioeng.9.061206.133100

32. Wassermann EM, Zimmermann T. Transcranial magnetic brain stimulation: therapeutic promises and scientific gaps. Pharmacol Therapeut 2012; 133(1): 98-107. https://doi.org/10.1016/j.pharmthera.2011.09.003

33. Rossini PM, Burke D, Chen R, Cohen LG, Daskalakis Z, Di Iorio $R$, ..., Hallett M.. Noninvasive electrical and magnetic stimulation of the brain, spinal cord, roots and peripheral nerves: basic principles and procedures for routine clinical and research application. An updated report from an IFCN Committee. Clin Neurophysiol 2015; 126(6): 1071-1107.

https://doi.org/10.1016/j.clinph.2015.02.001

34. Thut G, Pascual-Leone A. A Review of combined TMS-EEG studies to characterize lasting effects of repetitive TMS and assess their usefulness in cognitive and clinical neuroscience. Brain Topogr, 2010; 22: 219-232. https://doi.org/10.1007/s10548-009-0115-4

35. Huang YZ, Edwards MJ, Rounis E, Bhatia KP, Rothwell JC. Theta burst stimulation of the human motor cortex. Neuron 2005; 45: 201-206.

https://doi.org/10.1016/j.neuron.2004.12.033

36. Nitsche MA, Paulus W. Transcranial direct current stimulationupdate 2011. Restor Neurol Neurosci 2011; 29(6): 463-492.

37. Nitsche MA, Paulus W. Excitability changes induced in the human motor cortex by weak transcranial direct current stimulation. J Physiol London 2000; 527: 633-639.

https://doi.org/10.1111/j.1469-7793.2000.t01-1-00633.x

38. Pascual-Leone, A., Rubio, B., Pallardo, F., \& Catala, M. D. (1996). Rapid-rate transcranial magnetic stimulation of left dorsolateral prefrontal cortex in drug-resistant depression. Lancet 348(9022), 233-237. doi: 10.1016/S0140-6736(96)01219-6.

https://doi.org/10.1016/S0140-6736(96)01219-6

39. Oberman L, Edwards D, Eldaief M, Pascual-Leone A. Safety of theta burst transcranial magnetic stimulation: a systematic review of the literature. J Clin Neurophysiol 2011; 28(1): 67. https://doi.org/10.1097/WNP.0b013e318205135f

40. Brunoni AR, Amadera J, Berbel B, Volz MS, Rizzerio BG, Fregni F. A systematic review on reporting and assessment of adverse effects associated with transcranial direct current stimulation. Int J Neuropsychopharmacol 2011; 14(8): 1133-1145. https://doi.org/10.1017/S1461145710001690

41. Benninger DH, Iseki K, Kranick S, Luckenbaugh DA, Houdayer E, Hallett M. Controlled study of $50-\mathrm{Hz}$ repetitive transcranial magnetic stimulation for the treatment of Parkinson disease. Neurorehabil Neural Repair 2012; 26(9): 1096-1105. https://doi.org/10.1177/1545968312445636

42. Mantovani A, Simpson HB, Fallon BA, Rossi S, Lisanby SH. Randomized sham-controlled trial of repetitive transcranial magnetic stimulation in treatment-resistant obsessive-compulsive disorder. Int J Neuropsychopharmacol 2010; 13(2): 217-227. https://doi.org/10.1017/S1461145709990435

43. Dougall N, Maayan N, Soares-Weiser K, Mcdermott LM, Mcintosh A. Transcranial magnetic stimulation (TMS) for schizophrenia. Cochrane Database Syst Rev, 2015; 8.

https://doi.org/10.1002/14651858.CD006081.pub2 
44. Karsen, EF, Watts BV, Holtzheimer PE. Review of the effectiveness of transcranial magnetic stimulation for post-traumatic stress disorder. Brain Stimul 2014; 7: 151-157.

https://doi.org/10.1016/j.brs.2013.10.006

45. Sabesan P, Lankappa S, Khalifa N, Krishnan V, Gandhi R, Palaniyappan L. Transcranial magnetic stimulation for geriatric depression: promises and pitfalls. World J Psychiatry 2015; 5(2): 170-181.

https://doi.org/10.5498/wjp.v5.i2.170

46. Brevet-Aeby C, Brunelin J, Iceta S, Padovan C, Poulet E. Prefrontal cortex and impulsivity: interest of noninvasive brain stimulation. Neurosci Biobehav Rev, 2016; 71: 112-134. https://doi.org/10.1016/j.neubiorev.2016.08.028

47. Kuo MF, Paulus W, Nitsche MA. Therapeutic effects of noninvasive brain stimulation with direct currents (tDCS) in neuropsychiatric diseases. NeuroImage 2014; 85: Pt 3, 948-960. https://doi.org/10.1016/j.neuroimage.2013.05.117

\section{NEINVAZINIŲ SMEGENŲ STIMULIAVIMO METODŲ NAUDOJIMAS IMPULSYVUMUI MODULIUOTI}

\section{L.Mauer, Ch.Ch.Yang, N.Khalifa}

Raktažodžiai: impulsyvumas, TMS, tDCS, neinvazinis smegenų stimuliavimas, reakcijos slopinimas.
Santrauka

Šiame straipsnyje pateikiama literatūros apžvalga ir aptariami būsimų mokslinių tyrimų ir klinikinès praktikos padariniai.

Diagnostiniame ir statistiniame protinių sutrikimų žinyne impulsyvumas yra asmenybės konstrukcija, kuri laikoma pagrindiniu tam tikrų sutrikimų bruožu, ịskaitant ribinius ir antisocialinius asmenybès, dėmesio trūkumo, hiperaktyvumo, elgesio sutrikimus bei medžiagų vartojimo sutrikimus. Impulsyvumas turi neurobiologinị pagrindą, o impulsų kontrolè valdoma eilèje smegenų struktūrų, įskaitant ventromedialinę prefrontalinę žievę (vmPFC), užpakalinę lateralinę prefrontalų žievę (DLPFC), priekinę cinguliarinę žievę (ACC) ir limbines struktūras. Atliktų tyrimų duomenys rodo, kad impulsyvumui moduliuoti gali būti naudojami neinvaziniai smegenų stimuliavimo metodai, tokie kaip transkranialinė magnetinè stimuliacija (TMS) ir transkranialinè tiesioginès srovès stimuliacija (tDCS).

Adresas susirašinėti: najat.khalifa@nottingham.ac.uk

Gauta 2018-10-11 